\title{
ChemComm
}

Check for updates

Cite this: Chem. Commun., 2017, 53,8585

Received 7th June 2017

Accepted 5th July 2017

DOI: $10.1039 / c 7 c c 04398 h$

rsc.li/chemcomm

\section{Exploring structural complexity in the discovery and self-assembly of a family of nanoscale chalcoxides from $\left\{\mathrm{Se}_{8} \mathrm{Mo}_{36}\right\}$ to $\left\{\mathrm{Se}_{26} \mathrm{Mo}_{68}\right\} \dagger$}

\author{
Hong-Ying Zang, Jamie W. Purcell, De-Liang Long, (D) Haralampos N. Miras (D)* \\ and Leroy Cronin (D) *
}

\begin{abstract}
Herein, we show the controlled generation of multi-component libraries based on the $\left[\mathrm{Mo}_{2} \mathrm{~S}_{2} \mathrm{O}_{2}\right]^{2+} / \mathrm{Mo}^{\mathrm{VI}} \mathrm{O}_{4}{ }^{2-} / \mathrm{Se}^{\mathrm{IV}} \mathrm{O}_{3}{ }^{2-} / \mathrm{C}_{4} \mathrm{O}_{4}{ }^{2-}$ system leading to the formation of a whole new family of nanosized molecular chalcoxides, $\left\{\mathrm{Se}_{8} \mathrm{Mo}_{36}\right\} 1,\left\{\mathrm{Se}_{8} \mathrm{Mo}_{40}\right\} 2,\left\{\mathrm{Se}_{8} \mathrm{Mo}_{56}\right\} 3,\left\{\mathrm{Se}_{20} \mathrm{Mo}_{56}\right\}$ 4 and $\left\{\mathrm{Se}_{26} \mathrm{Mo}_{68}\right\} 5$, of the general formula $\left\{\left(\mathrm{Mo}_{2}^{\mathrm{V}} \mathrm{O}_{2} \mathrm{~S}_{2}\right)_{a}(\mathrm{OH})_{b}\left(\mathrm{Se}^{\mathrm{IV}} \mathrm{O}_{3}\right)_{c^{-}}\right.$ $\left.\left(\mathrm{C}_{4} \mathrm{O}_{4}\right)_{d}\left(\mathrm{Mo}_{2}^{\mathrm{V}} \mathrm{O}_{7}\right)_{e}\right\}^{n-}$, where $a, b, c, d, e, n=[16,20,8,6,2,20]$ for 1 , $[18,24,8,6,2,20]$ for $2,[24,32,8,8,4,24]$ for $3,[28,32,20,8,0,32]$ for 4 and $[34,36,26,8,0,36]$ for 5 . The coordination modulation effect offered by the $\mathrm{Se}^{\mathrm{IV}} \mathrm{O}_{3}{ }^{2-}$ and the $\mathrm{C}_{4} \mathrm{O}_{4}{ }^{2-}$ anions lead to the generation of new building blocks, $\left[\left(\mathrm{Mo}_{2}^{\mathrm{V}} \mathrm{O}_{2} \mathrm{~S}_{2}\right)_{3}(\mathrm{OH})_{6}\left(\mathrm{C}_{4} \mathrm{O}_{4}\right)\left(\mathrm{Mo}_{2}^{\mathrm{V}} \mathrm{O}_{7}\right)\right]^{4-}$, and the discovery of a new family of clusters of increasing nuclearity and complexity.
\end{abstract}

The self-assembly of supramolecular chemical systems is a key synthetic approach for the formation of a whole range of systems ranging from coordination cages ${ }^{1-3}$ to metal organic frameworks $^{4,5}$ and supramolecular coordination complexes. ${ }^{6}$ In these systems the chemical properties of the components (metal ions, ligands etc.) along with their underlying self-assembly processes, can be controlled to a degree. This understanding allowed the introduction of design elements which are mainly responsible for the formation of topologies of increased complexity rather than serendipity ${ }^{1}$ whilst the resulting architectures can even be post synthetically modified. ${ }^{7}$

In this respect, polyoxometalate and oxothiometalate-based structures represent a challenge since the ligand design tools are more limited. For example oxothiometalates ${ }^{8,9}$ are a family of inorganic molecular metal oxide systems whose structures are governed by self-assembly processes. ${ }^{10}$ The underlying selfassembly processes are effectively masked by the one-pot process but are macroscopically controlled by a series of experimental variables such as concentration/type of metal oxide anion, $\mathrm{pH}$, ion paring

School of Chemistry, WestCHEM, The University of Glasgow, Glasgow, G12 8QQ, UK.E-mail: harism@chem.gla.ac.uk, lee.cronin@glasgow.ac.uk

$\dagger$ Electronic supplementary information (ESI) available: Materials, instrumentation, synthesis, crystallographic procedures and data (CIF), UV-vis spectra studies. CCDC 1540787-1540791. For ESI and crystallographic data in CIF or other electronic format see DOI: 10.1039/c7cc04398h effects, heteroatoms, ligands, temperature and templates. ${ }^{11}$ However, recent work has shown that polyoxometalate chemistry is supramolecular in many aspects i.e., in the organization of small fragments into larger species ${ }^{12}$ and the fact that even the molecular clusters can be treated as a set of transferable building blocks. ${ }^{10}$

One key aim is to explore and explain how complex structures can be produced by control of the process variables (order of addition, $\mathrm{pH}$, use of salts), rather than only by ligand design. In this respect we have targeted inorganic structures as they lack preorganized organic ligands to see if we can firstly make large molecules without pre-designed ligands and then investigate any correlation between the complexity of the observed topologies, and the diversity of the library of available constituents. ${ }^{13,14}$ Additionally, control of the self-assembly of molecular architectures, especially those that are predominately inorganic, is a challenge due to the limited design flexibility with the templating ligands.

In order to explore this idea we investigated the reaction of $\mathrm{Mo}^{\mathrm{VI}} \mathrm{O}_{4}{ }^{2-}$ with $\left[\mathrm{Mo}_{2} \mathrm{O}_{2} \mathrm{~S}_{2}\right]^{2+}$ in the presence of $\mathrm{C}_{4} \mathrm{O}_{4}{ }^{2-}$ and $\mathrm{Se}^{\mathrm{IV}} \mathrm{O}_{3}{ }^{2-}$ based on the hypothesis that we should be able to form large molecular nanostructures, and then see if control could be achieved by manipulating the process variables. We chose the squarate and selenite anions not only to template the self-condensation of $\left[\mathrm{Mo}_{2}^{\mathrm{V}} \mathrm{S}_{2} \mathrm{O}_{2}\left(\mathrm{H}_{2} \mathrm{O}\right)_{6}\right]^{2+}$ we also hoped that together they would increase the diversity of new building block libraries. This is because we know that both ligands can act as templates as well as linkers of the available building blocks leading to a competition based modulation of the self-assembly process. This approach was very successful and we were able to isolate 5 new compounds as shown in Fig. 1.

These 5 compounds are formed by the condensation of the $\left[\mathrm{Mo}_{2}^{\mathrm{V}} \mathrm{S}_{2} \mathrm{O}_{2}\left(\mathrm{H}_{2} \mathrm{O}\right)_{6}\right]^{2+}$ leading to the formation of $\left\{\left[\left(\mathrm{Mo}_{2}^{\mathrm{V}} \mathrm{O}_{2} \mathrm{~S}_{2}\right)_{3}(\mathrm{OH})_{4^{-}}\right.\right.$ $\left.\left.\left(\mathrm{C}_{4} \mathrm{O}_{4}\right)\right]_{5}\left(\mathrm{Se}^{\mathrm{IV}} \mathrm{O}_{3}\right)_{8}\left(\mathrm{Mo}_{2}^{\mathrm{VI}} \mathrm{O}_{7}\right)_{2}\left(\mathrm{Mo}_{2}^{\mathrm{V}} \mathrm{O}_{2} \mathrm{~S}_{2}\right)\left(\mathrm{C}_{4} \mathrm{O}_{4}\right)\right\}^{20-}=\left\{\mathrm{Se}_{8} \mathrm{Mo}_{36}\right\}=$ $\left\{\mathrm{A}_{3} \mathrm{C}_{2} \mathrm{D}\right\}, \mathbf{1},\left\{\left[\left(\mathrm{Mo}_{2}^{\mathrm{V}} \mathrm{O}_{2} \mathrm{~S}_{2}\right)_{3}(\mathrm{OH})_{4}\left(\mathrm{C}_{4} \mathrm{O}_{4}\right)\right]_{6}\left(\mathrm{Se}^{\mathrm{IV}} \mathrm{O}_{3}\right)_{8}\left(\mathrm{Mo}_{2}^{\mathrm{VI}} \mathrm{O}_{7}\right)_{2}\right\}^{20-}=$ $\left\{\mathrm{Se}_{8} \mathrm{Mo}_{40}\right\}=\left\{\mathrm{A}_{4} \mathrm{C}_{2}\right\}, 2,\left\{\left[\left(\mathrm{Mo}_{2}^{\mathrm{V}} \mathrm{O}_{2} \mathrm{~S}_{2}\right)_{3}(\mathrm{OH})_{4}\left(\mathrm{C}_{4} \mathrm{O}_{4}\right)\right]_{3}\left(\mathrm{Mo}_{2}^{\mathrm{VI}} \mathrm{O}_{7}\right)_{2}\left(\mathrm{Se}^{\mathrm{IV}} \mathrm{O}_{3}\right)_{42^{-}}\right.$ $\left.\left[\left(\mathrm{Mo}_{2}^{\mathrm{V}} \mathrm{O}_{2} \mathrm{~S}_{2}\right)_{3}(\mathrm{OH})_{4}\left(\mathrm{C}_{4} \mathrm{O}_{4}\right)\right]_{2}\right\}^{24-}=\left\{\mathrm{Se}_{8} \mathrm{Mo}_{56}\right\}=\left\{\mathrm{A}_{4} \mathrm{C}_{4}\right\}, 3\left\{\left[\left(\mathrm{Mo}_{2} \mathrm{O}_{2} \mathrm{~S}_{2}\right)_{3}-\right.\right.$ $\left.\left.(\mathrm{OH})_{4}\left(\mathrm{C}_{4} \mathrm{O}_{4}\right)\right]_{8}\left[\left(\mathrm{Mo}_{2}^{\mathrm{V}} \mathrm{O}_{2} \mathrm{~S}_{2}\right)_{2}\left(\mathrm{Se}^{\mathrm{IV}} \mathrm{O}_{3}\right)_{8}\right]_{2}\left(\mathrm{Se}^{\mathrm{IV}} \mathrm{O}_{3}\right)_{4}\right\}^{32-}=\left\{\mathrm{Se}_{20} \mathrm{Mo}_{56}\right\}=$ $\left\{\mathrm{A}_{8} \mathrm{D}_{4}\right\}, 4$ and $\left\{\left[\left(\mathrm{Mo}_{2}^{\mathrm{V}} \mathrm{O}_{2} \mathrm{~S}_{2}\right)_{3}(\mathrm{OH})_{4}\left(\mathrm{C}_{4} \mathrm{O}_{4}\right)\right]_{8}\left[\left(\mathrm{Mo}_{2}^{\mathrm{V}} \mathrm{O}_{2} \mathrm{~S}_{2}\right)_{2}(\mathrm{OH})_{2}\left(\mathrm{Se}^{\mathrm{IV}} \mathrm{O}_{3}\right)\right]_{2^{-}}\right.$ $\left.\left[\left(\mathrm{Mo}_{2}^{\mathrm{V}} \mathrm{O}_{2} \mathrm{~S}_{2}\right)\left(\mathrm{Se}^{\mathrm{IV}} \mathrm{O}_{3}\right)_{4}\right]_{6}\right\}^{36-}=\left\{\mathrm{Se}_{26} \mathrm{Mo}_{68}\right\}=\left\{\mathrm{A}_{8} \mathrm{~B}_{2} \mathrm{D}_{6}\right\}, \mathbf{5}$. 


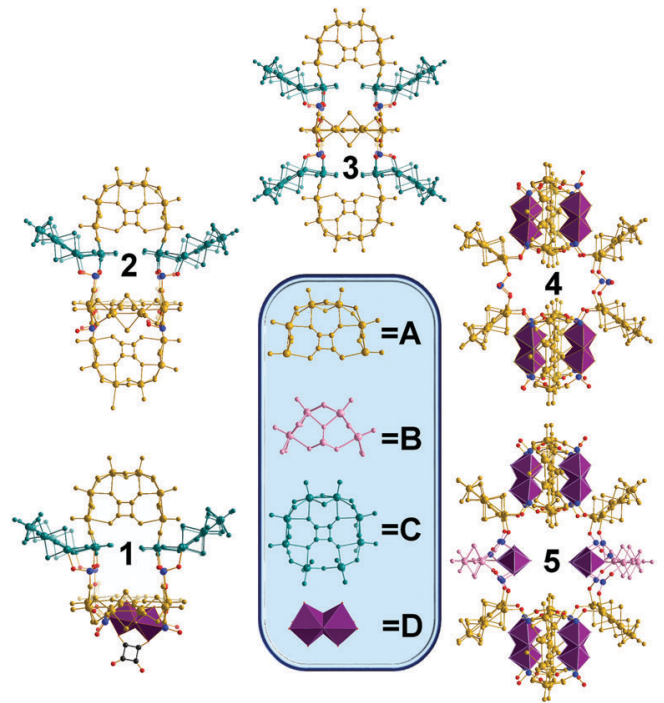

Fig. 1 Representation of the five clusters. The inset displays the common building blocks A-D highlighted in representative colours.

The structures are unusual in so far as they combine full and half-ring building blocks whereby "open" rings of $\left[\left(\mathrm{Mo}_{2}^{\mathrm{V}} \mathrm{O}_{2} \mathrm{~S}_{2}\right)_{3}\right.$ $\left.(\mathrm{OH})_{4}\left(\mathrm{C}_{4} \mathrm{O}_{4}\right)\right]=\left\{\mathrm{Mo}_{6}\right\}$ (type A building blocks) can be combined with $\left[\left(\mathrm{Mo}_{2}^{\mathrm{V}} \mathrm{O}_{2} \mathrm{~S}_{2}\right)_{2}(\mathrm{OH})_{2}\left(\mathrm{Se}^{\mathrm{IV}} \mathrm{O}_{3}\right)\right]=\left\{\mathrm{Mo}_{4}\right\}$ (type B building blocks), the new $\left[\left(\mathrm{Mo}_{2}^{\mathrm{V}} \mathrm{O}_{2} \mathrm{~S}_{2}\right)_{3}(\mathrm{OH})_{6}\left(\mathrm{C}_{4} \mathrm{O}_{4}\right) \mathrm{Mo}_{2}^{\mathrm{VI}} \mathrm{O}_{7}\right]=\left\{\mathrm{Mo}_{8}\right\}$ (type $\mathrm{C}$ building blocks) and the $\left[\mathrm{Mo}_{2}^{\mathrm{V}} \mathrm{O}_{2} \mathrm{~S}_{2}\right]=\left\{\mathrm{Mo}_{2}\right\}$ unit (type D building block) to construct a family of new nanosized clusters with the general formula of $\left\{\left(\mathrm{Mo}_{2}^{\mathrm{V}} \mathrm{O}_{2} \mathrm{~S}_{2}\right)_{a}(\mathrm{OH})_{b}\left(\mathrm{Se}^{\mathrm{IV}} \mathrm{O}_{3}\right)_{c}\left(\mathrm{C}_{4} \mathrm{O}_{4}\right)_{d}\left(\mathrm{Mo}_{2}^{\mathrm{VI}} \mathrm{O}_{7}\right)_{e}\right\}^{n-}$. This new type of assembly approach gives access to the formation of new building blocks which link together to yield a whole new range of elusive nuclearities ranging from $\left\{\mathrm{Mo}_{36}\right\}$ to $\left\{\mathrm{Mo}_{68}\right\}$. For example the structure of compound 3 combines type $\mathrm{C}$ and type $\mathrm{A}$ rings, see Fig. 2.

Compounds 1-3 formed under identical $\mathrm{pH}$ values, and the ratio of the two templates $\left(\mathrm{C}_{4} \mathrm{O}_{4} \mathrm{H}_{2}: \mathrm{Na}_{2} \mathrm{Se}^{\mathrm{IV}} \mathrm{O}_{3}\right)$ was in the range of $1.5: 1$ to $2: 1$. Any efforts to alter the $\mathrm{C}_{4} \mathrm{O}_{4} \mathrm{H}_{2}: \mathrm{Na}_{2} \mathrm{Se}^{\mathrm{IV}} \mathrm{O}_{3}$ ratio within the $1: 1$ and $1: 2$ range, always led first to the formation and crystallization of the $\mathrm{C}_{4} \mathrm{O}_{4}{ }^{2-}$ templated chiral $\left\{\mathrm{Mo}_{10}\right\}$ ring. ${ }^{13 a}$ However, fine adjustment of the amount of $\left[\mathrm{Mo}_{2} \mathrm{O}_{2} \mathrm{~S}_{2}\right]^{2+}$ species (see Experimental section) resulted in an increase of molybdenum nuclearity from 36 to 40 at room temperature. The same reaction mixture at slightly elevated temperature $\left(50{ }^{\circ} \mathrm{C}\right)$, led to the formation of 3 which incorporates 56 metal centres. The observed sensitivity of the chemical system reflects the complexity of the existing building block libraries and the co-existence of multiple dynamic equilibria between the system's constituents. In these three clusters, the squarate anions showed higher tendency to template the formation of building blocks in solution. The selenite anions, adopt a $\mu$ - and $\mu_{3}$-coordination mode, act as linkers and bridge the available building blocks into larger architectures.

Compound 1 crystallises in the monoclinic system $\left(P 2_{1} / n\right.$ space group) and the cluster in 1 exhibits an idealized $C_{2 \mathrm{v}}$ symmetry. More specifically, it is constructed by three $\left[\left(\mathrm{Mo}_{2}^{\mathrm{V}} \mathrm{O}_{2} \mathrm{~S}_{2}\right)_{3}(\mathrm{OH})_{4}\left(\mathrm{C}_{4} \mathrm{O}_{4}\right)\right]$ units and two $\left[\left(\mathrm{Mo}_{2}^{\mathrm{V}} \mathrm{O}_{2} \mathrm{~S}_{2}\right)_{3}(\mathrm{OH})_{6}\left(\mathrm{C}_{4} \mathrm{O}_{4}\right)\left(\mathrm{Mo}_{2}^{\mathrm{VI}} \mathrm{O}_{7}\right)\right]^{4-}$ building blocks

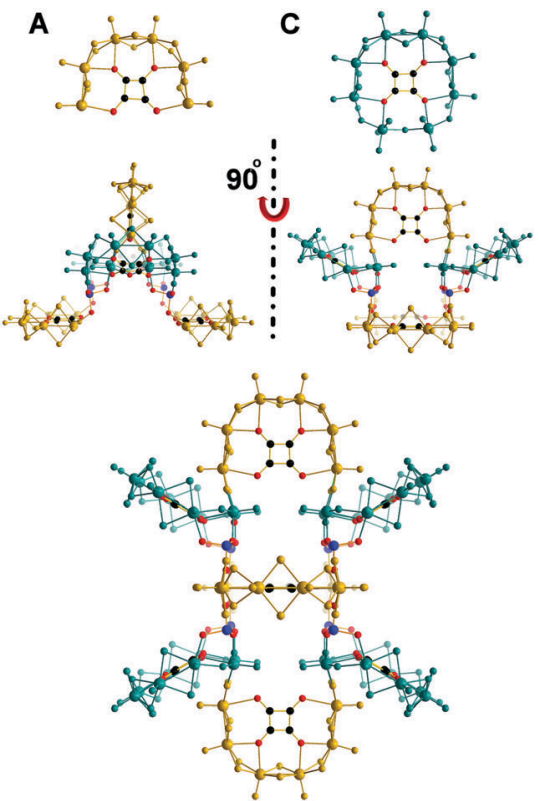

Fig. 2 Representation of the assembly of the $D_{2 \mathrm{~h}}$ symmetric $\left\{\mathrm{MO}_{56}\right\}=$ $\left\{\mathrm{A}_{4} \mathrm{C}_{4}\right\}$ (compound 3). Generation of the type $\mathrm{A}\left[\left(\mathrm{MoV}_{2}^{\mathrm{V}} \mathrm{O}_{2} \mathrm{~S}_{2}\right)_{3}(\mathrm{OH})_{4}\left(\mathrm{C}_{4} \mathrm{O}_{4}\right)\right]$ and a fundamentally new type $\mathrm{C}\left[\left(\mathrm{Mo}_{2}^{\mathrm{V}} \mathrm{O}_{2} \mathrm{~S}_{2}\right)_{3}(\mathrm{OH})_{6}\left(\mathrm{C}_{4} \mathrm{O}_{4}\right)\left(\mathrm{Mo}_{2}^{\mathrm{VI}} \mathrm{O}_{7}\right)\right]^{4-}$ building block with a curved topology.

which have been observed for the first time and have been effectively used for the construction of large chalcoxide architectures. Additionally, the insufficient amount of dimeric species led to the attachment of one $\left[\mathrm{Mo}_{2}^{\mathrm{V}} \mathrm{O}_{2} \mathrm{~S}_{2}\right]^{2+}$ unit along with an exposed $\left[\mathrm{C}_{4} \mathrm{O}_{4}\right]^{2-}$ unit at the bottom of the structure acting as a structural blocker preventing further growth of the architecture. Alternatively, increasing the number of available dimeric constituents directed the equilibrium towards the formation of additional type A building blocks replacing the bottom $\left[\mathrm{Mo}_{2} \mathrm{O}_{2} \mathrm{~S}_{2}\right]^{2+}$ and exposed $\left[\mathrm{C}_{4} \mathrm{O}_{4}\right]^{2-}$ unit to form cluster 2 which consists of four $\left[\left(\mathrm{Mo}_{2}^{\mathrm{V}} \mathrm{O}_{2} \mathrm{~S}_{2}\right)_{3}(\mathrm{OH})_{4}\left(\mathrm{C}_{4} \mathrm{O}_{4}\right)\right]$ and two $\left[\left(\mathrm{Mo}_{2}^{\mathrm{V}} \mathrm{O}_{2} \mathrm{~S}_{2}\right)_{3}(\mathrm{OH})_{6}\left(\mathrm{C}_{4} \mathrm{O}_{4}\right)-\right.$ $\left.\left(\mathrm{Mo}_{2}^{\mathrm{VI}} \mathrm{O}_{7}\right)\right]^{4-}$ building blocks, respectively. Cluster 2 exhibits the same $C_{2 \mathrm{v}}$ symmetry.

It is interesting that the equilibria established in the system can be disturbed further by careful adjustment of the temperature, which appears to affect the kinetics by leading to the faster formation of the type $\mathrm{C}\left[\left(\mathrm{Mo}_{2}^{\mathrm{V}} \mathrm{O}_{2} \mathrm{~S}_{2}\right)_{3}(\mathrm{OH})_{6}\left(\mathrm{C}_{4} \mathrm{O}_{4}\right)\left(\mathrm{Mo}_{2}^{\mathrm{VI}} \mathrm{O}_{7}\right)\right]$ building blocks leading to an increase of their population and their consecutive assembly into cluster 3 , see Fig. 2 . Compound 3 crystallises in the monoclinic system $(C 2 / m$ space group) and the cluster exhibits an idealized $D_{2 \mathrm{~h}}$ symmetry. The assembly of the cluster generates an accessible cavity of $1.2 \mathrm{~nm}$ in diameter (Fig. S2, ESI $\dagger$ ).

All three clusters exhibit two types of Mo-Mo contacts: a short Mo-Mo distance found to be ca. 2.8 $\AA$ within the dinuclear unit, characteristic of a metal-metal bond, and the long Mo-Mo distance of $c a$. 3.2 A which is in agreement with close non-bonding Mo-Mo separation found in the literature. ${ }^{13,14}$ The gradual increase of the concentration of the selenite anions in the reaction mixture and concurrent elimination of type $\mathrm{C}$ building blocks by exclusion of $\left[\mathrm{Mo}_{2}^{\mathrm{VI}} \mathrm{O}_{7}\right]^{2-}$ species, led to the 
A
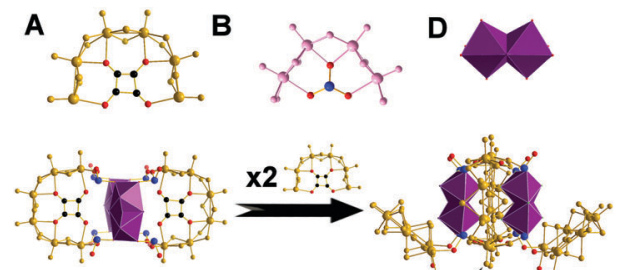

Fig. 3 Representation of the assembly of the $D_{2 h}$ symmetric $\left\{\mathrm{Mo}_{68}\right\}=$ $\left\{\mathrm{A}_{8} \mathrm{~B}_{2} \mathrm{D}_{6}\right\}$ (compound 5). Generation of the type $\mathrm{A}\left[\left(\mathrm{Mo}_{2}^{\mathrm{V}} \mathrm{O}_{2} \mathrm{~S}_{2}\right)_{3}(\mathrm{OH})_{4}\left(\mathrm{C}_{4} \mathrm{O}_{4}\right)\right]$ and type $\mathrm{B}\left[\left(\mathrm{Mo}_{2}^{\mathrm{V}} \mathrm{O}_{2} \mathrm{~S}_{2}\right)_{2}(\mathrm{OH})_{2}\left(\mathrm{Se}^{\mathrm{IV}} \mathrm{O}_{3}\right)\right]$ building block. The key role of the selenite anions and the dimeric $\left[\mathrm{MO}_{2}^{\mathrm{V}} \mathrm{O}_{2} \mathrm{~S}_{2}\right]^{2+}$ building block $\mathrm{D}$ connecting eight type A and two type B building blocks, is shown to allow their orthogonal alignment to the plane of the architecture and direct their assembly.

formation of cluster 4 with the formula, $\left\{\left[\left(\mathrm{Mo}_{2}^{\mathrm{V}} \mathrm{O}_{2} \mathrm{~S}_{2}\right)_{3}(\mathrm{OH})_{4^{-}}\right.\right.$ $\left.\left.\left(\mathrm{C}_{4} \mathrm{O}_{4}\right)\right]_{8}\left[\left(\mathrm{Mo}_{2}^{\mathrm{V}} \mathrm{O}_{2} \mathrm{~S}_{2}\right)_{2}\left(\mathrm{Se}^{\mathrm{IV}} \mathrm{O}_{3}\right)_{8}\right]_{2}\left(\mathrm{Se}^{\mathrm{IV}} \mathrm{O}_{3}\right)_{4}\right\}^{32-}$.

Cluster 4 crystallises in the triclinic system ( $P \overline{1}$ space group) exhibiting an idealized $D_{2 \mathrm{~h}}$ symmetry. It is constructed from eight $\left[\left(\mathrm{Mo}_{2}^{\mathrm{V}} \mathrm{O}_{2} \mathrm{~S}_{2}\right)_{3}(\mathrm{OH})_{4}\left(\mathrm{C}_{4} \mathrm{O}_{4}\right)\right]$ (type A) and four $\left[\mathrm{Mo}_{2}^{\mathrm{V}} \mathrm{O}_{2} \mathrm{~S}_{2}\right]^{2+}$ (type D) building blocks, Fig. 1 . The $D_{2 \mathrm{~h}}$ symmetric architecture of $\mathbf{4}$ is constructed by two larger components each formed by four type $\mathrm{A}$ and two type $\mathrm{D}$ units which are then bridged by four selenite anions to form $\left\{\mathrm{Se}_{20} \mathrm{Mo}_{56}\right\}$, see Fig. 1. Then, a further increase of the squarate: selenite ratio to $1: 1$, leads to the emergence of $\left[\left(\mathrm{Mo}_{2}^{\mathrm{V}} \mathrm{O}_{2} \mathrm{~S}_{2}\right)_{2}(\mathrm{OH})_{2}\left(\mathrm{Se}^{\mathrm{IV}} \mathrm{O}_{3}\right)\right]$ (type B) building blocks in the reaction mixture along with $\left[\left(\mathrm{Mo}_{2}^{\mathrm{V}} \mathrm{O}_{2} \mathrm{~S}_{2}\right)_{3}(\mathrm{OH})_{4}\left(\mathrm{C}_{4} \mathrm{O}_{4}\right)\right]$ (type A) and $\left[\mathrm{Mo}_{2}^{\mathrm{V}} \mathrm{O}_{2} \mathrm{~S}_{2}\right]^{2+}$ (type D), see Fig. 3 . In this case, the upper and lower components of the architecture are similar to the ones observed in $\mathbf{4}$ above, whereas these are bridged together by two type B building blocks and four selenite anions instead, allowing us to access the higher nuclearity of $\mathbf{5},\left\{\mathrm{Se}_{26} \mathrm{Mo}_{68}\right\}$ (Fig. 3). The multiple coordination modes of the selenite anions becomes evident in this case where they adopt a $\mu_{3}$-coordination mode as linkers and a $\mu_{4}$-mode as templates which promote the generation of the type $\mathrm{B}\left[\left(\mathrm{Mo}_{2}^{\mathrm{V}} \mathrm{O}_{2} \mathrm{~S}_{2}\right)_{2}(\mathrm{OH})_{2}\left(\mathrm{SeO}_{3}\right)\right]$ building block.

This study demonstrates a new assembly approach where exploitation of a coordination modulation effect offered by a choice of ligands of appropriate rigidity and coordination ability allowed the construction of a new supramolecular chalcoxide family 1-5. Only control over the process parameters e.g. the $\mathrm{C}_{4} \mathrm{O}_{4}{ }^{2-}: \mathrm{SeO}_{3}{ }^{2-}$ ratio provides a means to tailor the competition between the dynamic equilibria, finely tune the population of specific building blocks, and this controls the final cluster formed with everything else being kept equal in terms of the components present in solution. This means that the modulation of the interactions promoted by the competition between the dynamic building block libraries gives rise to the formation of the new building blocks which in turn lead to the new clusters with elaborate architectures. We envisage that further systematic tailoring of the steric, structural and electronic properties of ligands will induce new modes of controlling the generation of new BB libraries, their interactions and self-organization within chemical systems, enabling the tailored design of topologies and functionality.

The authors would like to thank the EPSRC (grants EP/L023652/1, EP/K023004/1, EP/H024107/1, EP/I033459/1 and $\mathrm{EP} / \mathrm{J} 015156 / 1$ ), the University of Glasgow, and the ERC (project 670467 SMART-POM) for supporting this work. H. N. M. thanks the Royal Society of Edinburgh and Marie Curie Actions for financial support.

\section{Notes and references}

1 D. Fujita, Y. Ueda, S. Sato, N. Mizuno, T. Kumasaka and M. Fujita, Nature, 2016, 540, 563-567.

2 P. Mal, B. Breiner, K. Rissanen and J. R. Nitschke, Science, 2009, 324, 1697-1699.

3 (a) M. M. J. Smulders, I. A. Riddell, C. Browne and J. R. Nitschke, Chem. Soc. Rev., 2013, 42, 1728-1754; (b) D. Fujita, H. Yokoyama, Y. Ueda, S. Sato and M. Fujita, Angew. Chem., Int. Ed., 2015, 54, 155-158.

4 R. S. Forgan, J.-P. Sauvage and J. F. Stoddart, Chem. Rev., 2011, 111, 5434-5464.

5 H. Furukawa, K. E. Cordova, M. O'Keeffe and O. M. Yaghi, Science, 2013, 341, 1230444.

6 B. J. Holliday and C. A. Mirkin, Angew. Chem., Int. Ed., 2001, 40, 2022-2043.

7 S. M. Jansze, G. Cecot, M. D. Wise, K. O. Zhurov, T. K. Ronson, A. M. Castilla, A. Finelli, P. Pattison, E. Solari, R. Scopelliti, G. E. Zelinskii, A. V. Vologzhanina, Y. Z. Voloshin, J. R. Nitschke and K. Severin, J. Am. Chem. Soc., 2016, 138, 2046-2054.

8 (a) F. Bannani, S. Floquet, N. Leclerc-Laronze, M. Haouas, F. Taulelle, J. Marrot, P. Kögerler and E. Cadot, J. Am. Chem. Soc., 2012, 134, 19342-19345; (b) C. Schäffer, A. M. Todea, H. Bögge, E. Cadot, P. Gouzerh, S. Kopilevich, I. A. Weinstock and A. Müller, Angew. Chem., Int. Ed., 2011, 50, 12326-12329.

9 (a) E. Cadot, M. N. Sokolov, V. P. Fedin, C. Simonnet-Jegat, S. Floquet and F. Secheresse, Chem. Soc. Rev., 2012, 41, 7335-7353; (b) H. El Moll, J. C. Kemmegne-Mbouguen, M. Haouas, F. Taulelle, J. Marrot, E. Cadot, P. Mialane, S. Floquet and A. Dolbecq, Dalton Trans., 2012, 41, 9955-9963; (c) S. Duval, S. Floquet, C. Simonnet-Jegat, J. Marrot, R. N. Biboum, B. Keita, L. Nadjo, M. Haouas, F. Taulelle and E. Cadot, J. Am. Chem. Soc., 2010, 132, 2069-2077; (d) S. Floquet, S. Brun, J. F. Lemonnier, M. Henry, M. A. Delsuc, Y. Prigent, E. Cadot and F. Taulelle, J. Am. Chem. Soc., 2009, 131, 17254-17259.

10 H. N. Miras, J. Yan., D.-L. Long and L. Cronin, Chem. Soc. Rev., 2012, 41, 7403-7430.

11 H. N. Miras, G. J. T. Cooper, D.-L. Long, H. Bögge, A. Müller, C. Streb and L. Cronin, Science, 2010, 327, 72-74.

12 B. S. Bassil, M. Ibrahim, R. Al-Oweini, M. Asano, Z. Wang, J. van Tol, N. S. Dalal, K.-Y. Choi, R. Ngo Biboum, B. Keita, L. Nadjo and U. Kortz, Angew. Chem., Int. Ed., 2011, 50, 5961-5964.

13 (a) H. Y. Zang, H. N. Miras, J. Yan, D. L. Long and L. Cronin, J. Am. Chem. Soc., 2012, 134, 11376-11379; (b) H. Y. Zang, H. N. Miras, D. L. Long, B. Rausch and L. Cronin, Angew. Chem., Int. Ed., 2013, 52, 6903-6906; (c) C. J. Richmond, H. N. Miras, A. R. de la Oliva, H. Y. Zang, V. Sans, L. Paramonov, C. Makatsoris, R. Inglis, E. K. Brechin, D. L. Long and L. Cronin, Nat. Chem., 2012, 4, 1038-1044.

14 (a) H. Y. Zang, J.-J. Chen, D. L. Long, L. Cronin and H. N. Miras, Chem. Sci., 2016, 7, 3798-3804; (b) H. Y. Zang, A. Surman, D. L. Long, L. Cronin and H. N. Miras, Chem. Commun., 2016, 52, 9109-9112; (c) H. Y. Zang, J.-J. Chen, D. L. Long, L. Cronin and H. N. Miras, Adv. Mater., 2013, 25, 6245-6249. 